\title{
Analisis Kemampuan Berpikir Kreatif Matematis Ditinjau dari Gaya Kognitif dan Gender
}

\author{
Nabila Ramadhani Maryanto ${ }^{1}$ dan Rizki Dwi Siswanto ${ }^{2 \bowtie}$ \\ ${ }^{1,2}$ Pendidikan Matematika, FKIP Universitas Muhammadiyah Prof. DR. HAMKA
}

\section{Info Artikel}

Sejarah Artikel:

Diterima 3 Mei 2021

Direvisi 11 Mei 2021

Disetujui 15 Mei 2021

Keywords: Mathematical Creative Thinking

Ability, Cognitive Style,

Reflecive, Impulsive,

Gender

Paper type:

Research paper

\section{Abstract}

This study aims to describe and analyze students' mathematical creative thinking ability in terms of cognitive style and gender. The research method used is descriptive qualitative. The sampling technique was purposive sampling with the subject of this study were 4 students, consisting of 1 male student with a reflective cognitive style, 1 male student with an Impulsive cognitive style, 1 female student with a reflective cognitive style, and 1 female students with Impulsive cognitive style. The instruments in this study were the Matching Familiar Figure Test (MFFT) and mathematical creative thinking skills. Data analysis in this study is by data reduction and categorization, data presentation, and drawing conclusions. The triangulation technique was used to validate the data by comparing the test results of the subject's mathematical creative thinking ability with the interview. The conclusion of this study is that male gender subjects (namely S1 and S3), both reflective and impulsive cognitive styles are more able to think more flexibly by providing some prism netting images or some correct answers when solving math problems than female gender subjects (namely S2 and S4) with reflective and impulsive cognitive style. Meanwhile, female gender subjects with impulsive cognitive style (S4) can provide detailed answers and have better accuracy than male gender subjects (S1 and S3).

\begin{abstract}
Abstrak
Penelitian ini bertujuan untuk mendeskripsikan dan menganalisis kemampuan berpikir kreatif matematis peserta didik ditinjau dari gaya kognitif dan gender. Metode penelitian yang digunakan adalah deskriptif kualitatif. Teknik pengambilan sampel yaitu purposive sampling dengan subjek penelitian ini adalah 4 peserta didik, terdiri dari 1 peserta didik laki-laki dengan gaya kognitif reflektif, 1 peserta didik laki-laki dengan gaya kognitif Impulsif, 1 peserta didik perempuan dengan gaya kognitif reflektif, dan 1 peserta didik perempuan dengan gaya kognitif Impulsif. Instrumen pada penelitian ini adalah Matching Familiar Figure Test (MFFT) dan kemampuan berpikir kreatif matematis. Analisis data dalam penelitian ini yaitu dengan reduksi data dan kategorisasi, penyajian data, dan penarikan kesimpulan. Teknik triangulasi dilakukan untuk melakukan keabsahan data yaitu membandingkan hasil tes kemampuan berpikir kreatif matematis subjek dengan wawancaranya. Kesimpulan penelitian ini bahwa subjek yang bergender laki-laki (yaitu S1 dan S3) baik bergaya kognitif reflective maupun impulsive lebih mampu berpikir lebih luwes dengan memberikan beberapa gambar jaring-jaring prisma atau beberapa jawaban benar ketika menyelesaikan masalah matematika dari pada subjek yang bergender perempuan (yaitu S2 dan S4) bergaya kognitif reflective maupun impulsive. Sedangkan, subjek yang bergender perempuan bergaya kognitif impulsive (S4) mampu memberikan jawaban secara terperinci dan memiliki ketelitian lebih baik daripada subjek bergender laki-laki (S1 dan S3).
\end{abstract}

\footnotetext{
Alamat korespondensi:

Program Studi Pendidikan Matematika

Fakultas Keguruan dan Ilmu Pendidikan Universitas Muria Kudus

Kampus UMK Gondangmanis, Bae Kudus Gd. L. 1t I PO. BOX 53 Kudus

Tlp (0291) 438229 ex.147 Fax. (0291) 437198

E-mail: rizkidwisiswanto@uhamka.ac.id
}

p-ISSN 2615-4196

e-ISSN 2615-4072 


\section{PENDAHULUAN}

Revolusi industri 4.0 menuntut peserta didik untuk menguasai kecakapan dan keterampilan dalam matematika yaitu komunikasi, kolaborasi, kemampuan berpikir kritis dan pemecahan masalah, serta kreativitas. Tantangan masa depan yang selalu berubah sekaligus persaingan yang semakin ketat memerlukan lulusan yang tidak hanya terampil dalam satu bidang (Siswanto \& Azhar, 2018) tetapi juga mampu kreatif dan berkomunikasi dengan baik dalam mengembangkan bidang yang ditekuni. Kemampuan berpikir kreatif menjadi salah satu kebutuhan dalam menemukan ide dan solusi baru untuk menyelesaikan masalah, karena dewasa ini masalah utama peserta didik dalam pembelajaran matematika di sekolah adalah masih semata berorientasi pada upaya menguji daya ingat peserta didik dan hanya mencari satu jawaban yang benar sehingga kemampuan berpikir peserta didik direduksi untuk mengingat (Siswanto, 2016). Padahal menurut Sabandar (Siswanto, 2015) mengingat merupakan keterampilan atau kemampuan berpikir tingkat yang paling rendah.

Melalui pendidikan generasi muda yang berkualitas dihasilkan, karena minat bakat serta keterampilan peserta didik dikembangkan agar berguna bagi hidupnya (Siswanto \& Ratiningsih, 2020). Pembelajaran yang dilakukan harus mampu menjadi memfasilitasi peserta didik mengembangkan keterampilan berpikirnya. Siagian (Siswanto \& Ratiningsih, 2020) berpendapat salah satu indikator pendidikan yang baik apabila peserta didik mampu menerapkan konsep matematika dan menggunakannya untuk menyelesaikan permasalahan dikehidupan seharihari dalam berbagai situasi dan kondisi. Namun faktanya banyak peserta didik telah mengganggap matematika itu sulit sehingga berakibat proses berpikirnya menjadi rendah. Data hasil survey Programme for International Student Assessment (PISA) 2018 yang diterbitkan maret 2019 lalu memotret sekelumit masalah pendidikan Indonesia yang tergolong rendah dalam kategori kemampuan membaca, sains, dan matematika, karena berada di urutan ke-74 dari 79 negara (OECD, 2019). Hal ini memperlihatkan bahwa rendahnya proses berpikir peserta didik menjadikan Indonesia belum mampu bersaing dengan negara-negara lain.

Darmawan, Kharismawati, Hendriana, \& Purwasih (2018) berpendapat pembelajaran matematika tidak boleh fokus hanya pada perhitungan tetapi juga pada pembentukan kerangka berpikir untuk benalar sehingga peserta didik dapat berpikir kritis, logis dan kreatif. Proses berpikir matematis merupakan kebutuhan hidup sehari-hari yang terdapat penerapan konsep pembelajaran matematika. Berpikir kreatif secara sederhana kita sering gunakan ketika ingin menghasilkan sesuatu yang berbeda atau berinovasi (Siswanto, 2015; Siswanto \& Awalludin, 2018). Menurut Munandar (2016) kreativitas adalah hasil dari interaksi antara individu dan lingkungannya. Maksudnya, peserta didik yang kreatif mempunyai sifat selalu ingin tahu, memiliki minat yang luas, dan menyukai kegemaran dan aktivitas yang kreatif. Lebih lanjut menurut Williams (Munandar, 2016) kemampuan yang berkaitan dengan berpikir kreatif meliputi delapan kemampuan, empat dari ranah kognitif dan empat dari ranah afektif. Kemampuan kognitif dari kreatif antara lain ialah berpikir lancar, berpikir lentur (fleksibel), berpikir orisinal, dan berpikir elaboratif atau merinci. Sedangkan kemampuan afektif dari kreatif ialah rasa ingin tahu, mengambil resiko, kemajemukan, dan imajinasi.

Menurut Widayatun (Nuryadi \& Rahmawati, 2018) kreatif merupakan keterampilan untuk menciptakan suatu gagasan atau ide-ide asli untuk berkembang dalam menyelesaikan suatu permasalahan, kreativitas juga dimaksudkan sebagai keterampilan atau kemampuan seseorang. Jumanta Hamdayama (Kalida, 2016) berpendapat pembelajaran kreatif terdapat beberapa karakter penting yaitu berpusat pada anak atau peserta didik (student center), memberikan pengalaman pada anak (direct experience), pemisahan mata pelajaran tak begitu jelas, bersifat luwes (fleksibel), menyajikan konsep dari berbegai mata pelajaran dalam proses pembelajaran, dan hasil pembelajaran dapat berkembang sesuai dengan minat dan kebutuhan anak. Beberapa pengertian tentang berpikir kreatif, pada dasarnya ada persamaan antara beberapa pengertian tersebut, yaitu keterampilan menciptakan pembaruan atau mengembangkan sesuatu yang ada menjadi pembaruan. Berpikir kreatif mengaitkan keterampilan untuk menghasilkan ide-ide orisinil, membuat dan membentuk suatu rangkaian yang baru dan unik dari beberapa konsep yang ada.

Munandar (2016) mencirikan siswa keterampilan peserta didik dalam berpikir kreatif yaitu 1) kelancaran, 2) keluwesan, 3) orisinal, 4) mampu merinci, dan 5) mampu mengevaluasi. Guilford (Siswanto, 2015, 2016; Siswanto \& Awalludin, 2018) juga mencirikan empat karakteristik kognitif berpikir kreatif yaitu kelancaran (fluency), keaslian (orisinility), keluwesan (fleksibility), dan terperinci (elaboration). Masih banyak karakteristik tentang kemampuan berpikir kreatif yang dikemukakan oleh para ahli di bidang tersebut. Namun, karakteristik atau indikator yang dijelaskan oleh Guilford nampak sangat jelas dan terperinci karena 
dilakukan melalui usaha-usaha penelitian berbasis proses berpikir kreatif. Oleh karena itu, pada penelitian ini indikator yang digunakan antara lain: (1) kelenturan (flexibility), (2) kelancaran (fluency), dan (3) terperinci (elaboration). Berdasarkan pendapat Guliford indikator berpikir kreatif terdapat 4, tetapi pada penelitian ini indikator keaslian (Originality) tidak digunakan karena peserta didik yang akan menjadi subjek dirasa belum bisa mneciptakan ide-ide baru.

Kemampuan matematis tiap peserta didik berbeda sesuai dengan kemampuan peserta didik tersebut dalam memproses informasi (Nurmalia, Yuhana, \& Fatah, 2019). Perbedaan kesulitan yang peserta didik alami dalam memproses dan menggunakan informasi yang diterima merupakan salah satu pengaruh dari gaya kognitif. Hal ini dikarenakan gaya kognitif berpengaruh terhadap pemrosesan informasi dalam otak peserta didik sehingga akan terjadi perbedaan penyampaian ideide matematis peserta didik pada masing-masing gaya kognitif (Achir, Usodo, \& Retiawan, 2017). Gaya kognitif terdiri dari beberapa jenis, diantaranya adalah reflektif dan impulsif. Kagan (Wardhana \& Lutfianto, 2018) menjelaskan bahwa dimensi reflektif dan impulsif mengambarkan kecenderungan peserta didik yang tetap untuk menunjukkan cepat atau lambat waktu menjawab terhadap situasi masalah dengan ketidakpastian jawaban yang tinggi.

Gaya kongitif adalah salah satu variabel belajar yang harus dipertimbangkan untuk melaksanakan proses pembelajaran. Fadiana (2016) berpendapat kesuksesan dalam memperoleh pesan matematika juga ditentukan oleh gaya kognitif. Kecepatan berpikir dapat atau disebut kognitif dapat dilihat dari gaya kognitif reflektif dan impulsif. Menurut Woolfolk, gaya kognitif adalah suatu cara yang berbeda untuk melihat, mengenal, dan mengorganisasi informasi (Aldarmono, 2012). Sedangkan menurut Sternberg dan Elena (Nurmalia et al., 2019) gaya kognitif adalah jembatan antara kecerdasan dan kepribadian. Sudia, Budayasa, \& Lukito (2014) mengemukakan gaya kognitif tipe reflektif dan impulsif.

Menurut Kagan (Aprilia, Sunardi, \& Trapsilasiwi, 2017; Rozencwajg \& Corroyer, 2005) gaya kognitif reflective tercermin pada seseorang memiliki karakteristik tidak cepat atau lambat dalam menanggapi permasalahan tetapi lebih cermat atau berhati-hati sehingga jawaban soal yang didapat cenderung bagus atau diperbaiki, artinya seseorang yang selalu berpikir terlebih dahulu saat diberikan soal pertanyaan atau permasalahan merupakan tipe gaya kognitif reflective. Selanjutnya, Kagan (Suprihatin, Maya,
\& Senjayawati, 2018) Gaya kognitif impulsive tercermin pada seseorang mempunyai karakteristik tanggap dalam menjawab soal tetapi kurang hatihati, artinya seseorang yang refleks dalam menjawab soal dan menulis semua ide yang ada pada pikirannya merupakan tipe gaya kognitif impulsive. Dalam penelitian ini, indikator yang dinyatakan oleh Kagan (1966) yang kemudian dikembangkan oleh Warli (2010) akan digunakan dalam mengukur gaya kognitif.

Selain gaya kognitif, gender juga merupakan faktor yang membedakan peserta didik dalam belajar dan mengolah informasi (Nur \& Palobo, 2018). Atribut yang berhubungan dengan jenis kelamin, termasuk peran, tingkah laku, preferensi yang menerangkan kelaki-lakian atau kewanitaan dalam konteks budaya tertentu dapat disebut Gender (Hoang, 2008). Gender dapat memberdakan proses seseorang berpikir dan mencari ide serta cara berkomunikasi yang diambil. Ketika dihadapkan sebuah masalah, peserta didik laki-laki dan perempuan memiliki kreativitas dan komunikasi dalam mengungkapkan ide yang cenderung berbeda. Gender dalam penelitian ini dibedakan menjadi laki-laki dan perempuan, oleh karena itu cukup menarik jika dilakukan penelitian untuk melihat bagaimana peran gender dalam proses berpikir peserta didik.

Berdasarkan penjelasan di atas mengenai kemampuan berpikir atau memproses informasi gaya kognitif baik reflective maupun impulsive dan gender baik laki-laki maupun perempuan, memiliki karakteristik yang berbeda diantara keduanya. Gaya kognitif dan gender memberikan gambaran kesiapan seseorang dalam merespon suatu pertanyaan dan permasalahan. Hal ini berkaitan dengan kemampuan berpikir kreatif peserta didik, karena dari gaya kognitif dan gender akan mempengaruhi peserta didik dalam membuat suatu ide kreatif dalam pembelajara. Adapun tujuan dari penelitian ini untuk mendeskripsikan dan menganalisis kemampuan berpikir kreatif matematis peserta didik yang ditinjau dari gaya kognitif dan gender.

\section{METODE PENELITIAN}

Penelitian ini menggunakan jenis penelitian deskriptif kualitatif dengan tujuan untuk mendeskripsikan tentang kemampuan berpikir kreatif matematis ditinjau dari gaya kognitif dan gender. Penelitian dilakukan di SMPIT Al-Ikhlas Bekasi via Zoom karena pada saat penelitian dalam kondisi pandemi Covid-19. Penentuan subjek penelitian menggunakan interumen Matching Familiar Figure Test (MFFT) yang dibuat oleh Kagan (1966) dan yang kemudian dikembangkan oleh Warli (2010). MFFT digunakan untuk 
mengkategorikan peserta didik yang mempunyai gaya kognitif reflective dan impulsive. Peserta didik mengerjakan soal MFFT tersebut dengan menggunakan Google Form yang sudah dibuat oleh peneliti dengan ketentuan peserta didik menuliskan waktu sebelum mengerjakan soal dan waktu setelah mengerjakan soal. Subjek penelitian yang didapat adalah 4 peserta didik, terdiri dari 1 peserta didik laki-laki dengan gaya kognitif Reflective, 1 peserta didik laki-laki dengan gaya kognitif Impulsive, 1 peserta didik perempuan dengan gaya kognitif Reflective, dan 1 peserta didik perempuan dengan gaya kognitif Impulsive.

Tes kemampuan berpikir kreatif yang dilakukan yaitu tes uraian berjumlah 3 soal dengan durasi 60 menit. Tujuan dari tes ini untuk mengukur kemampuan berpikir kreatif matematis subjek penelitian. Soal yang diberikan masingmasing sesuai dengan indikator berpikir kreatif yang telah pertimbangkan sebelumnya yaitu: (1) kelenturan (flexibility), (2) kelancaran (fluency), dan (3) terperinci (elaboration) serta sudah uji validasi ahli dan reliabilitasnya.

Wawancara dilakukan dengan metode semi terstruktur dengan menggunakan panduan pada proses wawancara untuk menggali lebih dalam kemampuan berpikir kreatif matematis subjek, namun peneliti juga bisa mengembangkan pertanyaannya pada saat wawancara dengan alur pembahasan yang masih tetap. Peneliti juga menggunakan dokumentasi sebagai alat bantu untuk mengumpulkan data berupa foto-foto, hasil jawaban peserta didik, dan video record wawancara via Zoom.

Analisis data dalam penelitian ini menggunakan model Miles dan Huberman, yaitu reduksi data dan kategorisasi, penyajian data, penarikan kesimpulan atau verifikasi (Sugiyono, 2018). Teknik triangulasi dilakukan untuk melakukan keabsahan data yaitu dengan membandingkan hasil tes kemampuan berpikir kreatif matematis subjek dengan wawancaranya.

\section{HASIL DAN PEMBAHASAN}

Tes MFFT diberikan kepada 37 peserta didik kelas VIII SMPIT Al-Ikhlas Bekasi via Google Form, kemudian peneliti menganalisis lama waktu pengerjaan dan hasil skor yang didapat dari setiap peserta didik. Tes tersebut menghasilkan 15 peserta didik bergaya kognitif Reflective dan 22 peserta didik bergaya Impulsive, kemudian peneliti memilih 1 peserta didik laki-laki dengan gaya kognitif Reflective, 1 peserta didik laki-laki dengan gaya kognitif Impulsive, 1 peserta didik perempuan dengan gaya kognitif Reflective, dan 1 peserta didik perempuan dengan gaya kognitif Impulsive sebagai subjek penelitian seperti pada tabel 1 . Terpilihnya empat subjek berdasarkan kelompok bergaya kognitif Reflective dan Impulsive, skor dan waktu yang diperoleh dari keempat subjek tersebut sesuai dengan kriteria dan memenuhi syarat sampel yang diinginkan.

Selanjutnya peneliti memberikan tes kemampuan berpikir kreatif matematis yang berjumlah 3 soal dengan masing-masing soal sesuai dengan indikator yang sudah ditentukan, tes ini diberikan kepada 4 subjek terpilih. Karena penelitian ini dilakukan saat pandemi COVID-19, maka tes dan wawancara dilakukan dengan menggunakan aplikasi Zoom. Data hasil tes kemampuan berpikir kreatif matematis sebagai berikut :

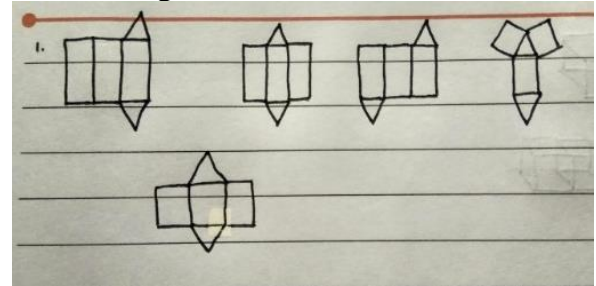

Gambar 1. Jawaban Nomor 1 dari Subjek 1

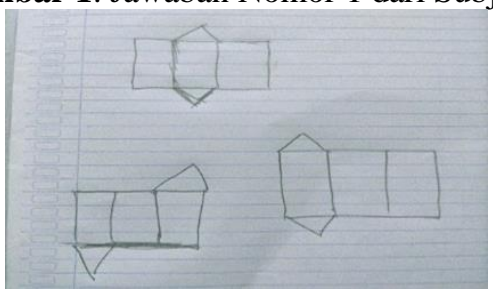

Gambar 2. Jawaban Nomor 1 dari Subjek 3

Soal nomor 1 dengan indikator flexibility yaitu menerapkan beberapa cara atau gambar dalam menyelesaikan permasalahan matematika atau mampu memberikan beberapa jawaban benar. Berdasarkan gambar 1 dan gambar 2, S1 dan S3 sudah mampu menjawab pertanyataan dengan memberikan beberapa jawaban yang benar. Sedangkan S2 dan S4 hanya mampu memberikan satu jawaban atas permasalahan yang diberikan.

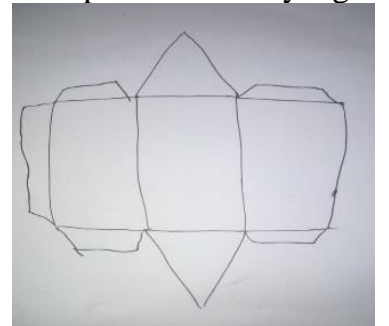

Gambar 3. Jawaban Nomor 1 dari Subjek 2

Tabel 1. Kategori Subjek Penelitian

\begin{tabular}{|c|c|c|c|c|c|}
\hline \multirow{2}{*}{ No } & \multirow{2}{*}{ Nama } & \multirow{2}{*}{ Gender } & \multirow{2}{*}{ Skor } & \multirow{2}{*}{ Waktu } & Gaya Kognitif \\
\hline & & & & & Reflektive Impulsive \\
\hline
\end{tabular}




\begin{tabular}{lcccccc}
\hline \multicolumn{1}{c}{} & & & & & \\
\hline 1 & AA & Laki-laki & 13 & $00: 37: 07$ & $\checkmark$ & \\
\hline 2 & FSR & Perempuan & 9 & $00: 29: 04$ & & $\checkmark$ \\
\hline 3 & SJN & Laki-laki & 2 & $00: 09: 33$ & & $\checkmark$
\end{tabular}

Berdasrkan jawaban yang diberikan oleh S2 pada gambar 3 di atas, peneliti melakukan wawancara kepada S2. Berikut cuplikan wawancara tentang soal nomor 1 untuk S2 disajikan pada Tabel 2.

Tabel 2. Cuplikan Wawancara Soal Nomor 1 untuk S2

\begin{tabular}{ll}
\hline & \multicolumn{2}{c}{ Subjek 2 } \\
\hline & $\begin{array}{l}\text { Di soal nomor 1 kan perintahnya diminta } \\
\text { membuat jaring-jaring prisma segitiga. }\end{array}$ \\
P: & $\begin{array}{l}\text { Diinstruksinya itu ada beberapa } \\
\text { kemungkinan. Kenapa Kamu cuma } \\
\\
\text { gambar itu aja? Yang tau itu doang? }\end{array}$ \\
\hline S2: & Iya taunya itu ajah \\
\hline P: & Kalo gambar lainnya ada, tau lagi gak? \\
\hline S2: & Ga kebayang
\end{tabular}

Berdasrkan cuplikan wawancara dengan S2 di atas, terlihat bahwa S2 hanya mampu memberikan satu jawaban atas permasalahan yang diberikan dan belum mampu menunjukkan ciri keluwesan dalam menjawab soal yang diberikan. Selanjutnya, hasil jawaban dari S4 dapat dilihat pada gambar di bawah ini

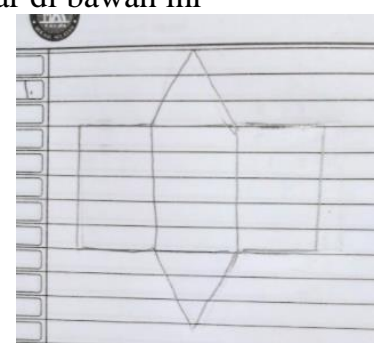

Gambar 4. Jawaban Nomor 1 dari Subjek 4

Berdasrkan jawaban yang diberikan oleh S4 pada gambar 4 di atas, peneliti melakukan wawancara kepada S4. Berikut cuplikan wawancara soal nomor 1 untuk S4 disajikan pada Tabel 3.

Tabel 3. Cuplikan Wawancara Soal Nomor Nomor 1 untuk S4 Subjek 4

Di soal nomer 1 kenapa kamu cuma P: $\quad$ gambar 1 doang? yang kamu tau itu aja atau karena buru-buru?

\begin{tabular}{ll}
\hline S4: & Itu aja \\
\hline P: & Kalo disuruh gambar lagi, tau ga? \\
\hline S4: & Ga bisa
\end{tabular}

Berdasrkan cuplikan wawancara dengan S4 di atas, dapat disimpulkan bahwa S4 juga hanya mampu memberikan satu jawaban atas permasalahan yang diberikan dan belum mampu menunjukkan ciri keluwesan dalam menjawab soal yang diberikan.

Soal nomor 2 dengan indikator fluency yaitu menghasilkan beragam gagasan/alternatif yang relevan dan arus pemikiran lancar. Secara umum, indikator ini belum dapat dicapai atau dikuasai oleh keempat subjek. Berikut jawaban S1 terhadap soal nomor 2 .

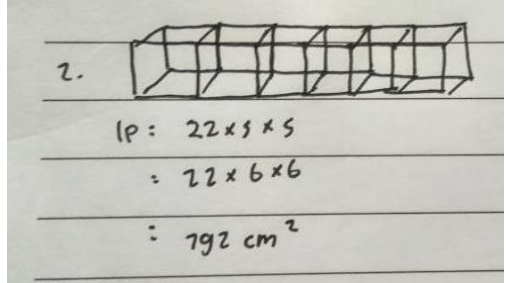

Gambar 5. Jawaban Nomor 2 dari Subjek 1

Berdasarkan gambar 5, walaupun S1 sudah mampu menggambar sebuah susunan kubus dengan benar dan mendapatkan jawaban yang benar, namun kurang lancar dalam menghasilkan beragam gagassan dalam arti hanya mampu memberikan satu jawaban atas permasalahan yang diberikan. Selanjutnya, hasil jawaban S3 terhadap soal nomor 2 .

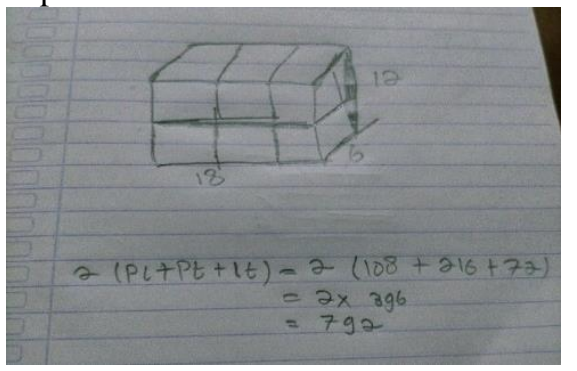

Gambar 6. Jawaban Nomor 2 dari Subjek 3

Berdasarkan gambar 6, walaupun S3 juga sudah mampu menggambar sebuah susunan kubus dengan benar dan mendapatkan jawaban yang benar, namun kurang lancar dalam menghasilkan beragam gagassan dalam arti hanya mampu memberikan satu jawaban atas permasalahan yang diberikan. Selanjutnya, hasil jawaban S2 terhadap soal nomor 2 . 


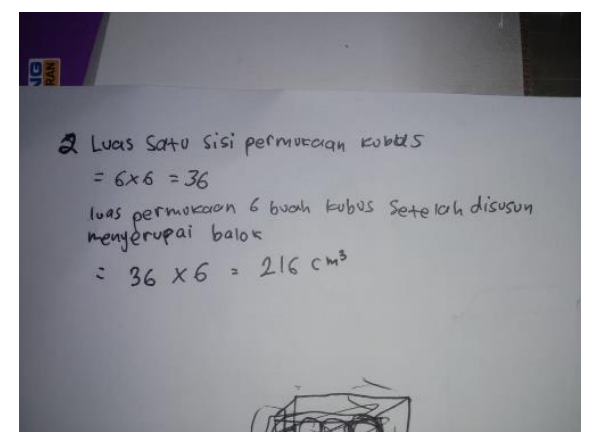

Gambar 7. Jawaban Nomor 2 dari Subjek 2

Berdasrkan jawaban yang diberikan oleh S2 pada gambar 7 di atas, terlihat bahwa S2 belum mampu menggambar susunan kubus dan belum menjawab dengan benar. Peneliti melakukan wawancara kepada S2. Berikut cuplikan wawancara soal nomor 2 untuk S2 disajikan pada Tabel 4.

Tabel 4. Cuplikan Wawancara Soal Nomor 2 untuk S2

\begin{tabular}{ll}
\hline \multicolumn{1}{c}{ Subjek 2 } \\
\hline P: & Untuk soal nomor 2 paham gak? \\
\hline S2: & Gak terlalu \\
& $\begin{array}{l}\text { Disitukan disuruh susun } 6 \text { kubus } \\
\text { menjadi sebuah balok, jadi disusun- } \\
\text { susun gitu. Nah dijawaban kamu itu } \\
\text { awalnya bener 6x6 = 36. nah tapi pas } \\
\text { bagian luas permukaannya kamu hanya } \\
\text { memasukkan 36x6, harusnya kamu } \\
\text { tambahin tinggi dari baloknya } 6 \text { cm, jadi }\end{array}$ \\
& 36x6x6 \\
\hline S2: & Oh iya maaf \\
\hline P: & $\begin{array}{l}\text { Gapapa kok, terus kamu jawab ini } \\
\text { darimaa? }\end{array}$ \\
\hline S2: & Dari google dan dibantu mamah, hehe \\
\hline P: & $\begin{array}{l}\text { Oh iya gapapa, terus itu ko gambarnya } \\
\text { kepotong? }\end{array}$ \\
\hline S2: & Itu cuma coret-coretan aja hehe
\end{tabular}

Berdasrkan cuplikan wawancara dengan S2 di atas, dapat disimpulkan bahwa S2 memang belum paham terhadap soal yang diberikan, sehingga tidak dapat menghasilkan beragam gagasan/alternatif yang relevan dan arus pemikiran lancar dalam mencari penyelesaian masalah yang diberikan. Selanjutnya, hasil jawaban S4 terhadap soal nomor 2.

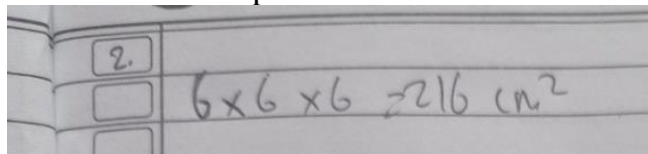

Gambar 8. Jawaban Nomor 2 dari Subjek 4

Berdasrkan jawaban yang diberikan oleh S4 pada gambar 8 di atas, terlihat bahwa S4 juga belum mampu menggambar susunan kubus dan belum menjawab dengan benar. Peneliti melakukan wawancara kepada S4. Berikut cuplikan wawancara soal nomor 2 untuk S4 disajikan pada Tabel 5.

Tabel 5. Cuplikan Wawancara Soal Nomor 2 untuk S4

\begin{tabular}{ll}
\hline \multicolumn{2}{c}{ Subjek 4} \\
\hline P: & Untuk soal nomer 2, kamu ga paham ya? \\
\hline S4: & Iya \\
P: & $\begin{array}{l}\text { Coba nomer 2, kamu masih inget gak } \\
\text { pertanyaannya? }\end{array}$ \\
\hline S4: & Lupa \\
& $\begin{array}{l}\text { Disitu diminta menyusun } 6 \text { kubus } \\
\text { menjadi sebuah balok, jadi disusun- } \\
\text { P: }\end{array}$ \\
& $\begin{array}{l}\text { susun gitu. Kamu bisa tolong susun } \\
\text { baloknya? }\end{array}$ \\
\hline S4: & Hmm, bisa \\
\hline P: & $\begin{array}{l}\text { Coba, saya tungguin nanti di kasih liat } \\
\text { saya yah. (setelah beberapa menit) }\end{array}$ \\
\hline S4: & Hmm, susah, aku gak bisa \\
\hline & Berdasrkan cuplikan wawancara dengan
\end{tabular}
S4 di atas, dapat disimpulkan bahwa S4 sudah paham terhadap soal yang diberikan, namun tidak mampu menghasilkan beragam gagasan/alternatif yang relevan dan arus pemikiran lancar dalam mencari penyelesaian masalah yang diberikan.

Soal nomor 3 dengan indikator elaboration yaitu memberikan jawaban secara terperinci dan memperluas daerah masalah yang diberikan. Berdasarkan jawaban yang diperoleh hanya S4 yang mampu menjawab soal ini dengan memberikan jawaban secara teliti, rinci, dan benar. Berikut jawaban S4 terhadap soal nomor 3.

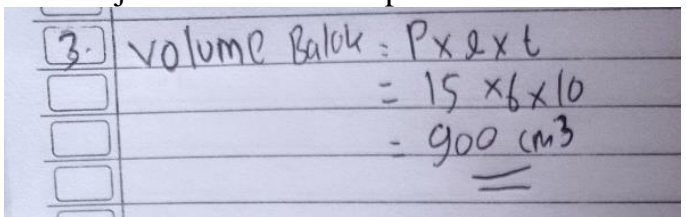

Gambar 9. Jawaban Nomor 3 dari Subjek 4

Sedangkan S1, S2, dan S3 belum mampu memberikan jawaban dengan teliti, rinci, dan benar. Jawaban S1 dapat dilihat pada gambar 10.

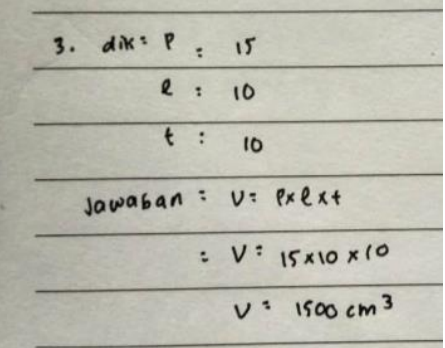

Gambar 10. Jawaban Nomor 3 dari Subjek 1

Berdasrkan jawaban yang diberikan oleh S1 pada gambar 10 di atas, terlihat bahwa S1 belum mampu memberikan jawaban dengan teliti, 
rinci, dan benar. Peneliti melakukan wawancara kepada S1. Berikut cuplikan wawancara soal nomor 3 untuk S1 disajikan pada Tabel 6.

Tabel 6. Cuplikan Wawancara Soal Nomor 3 untuk S1

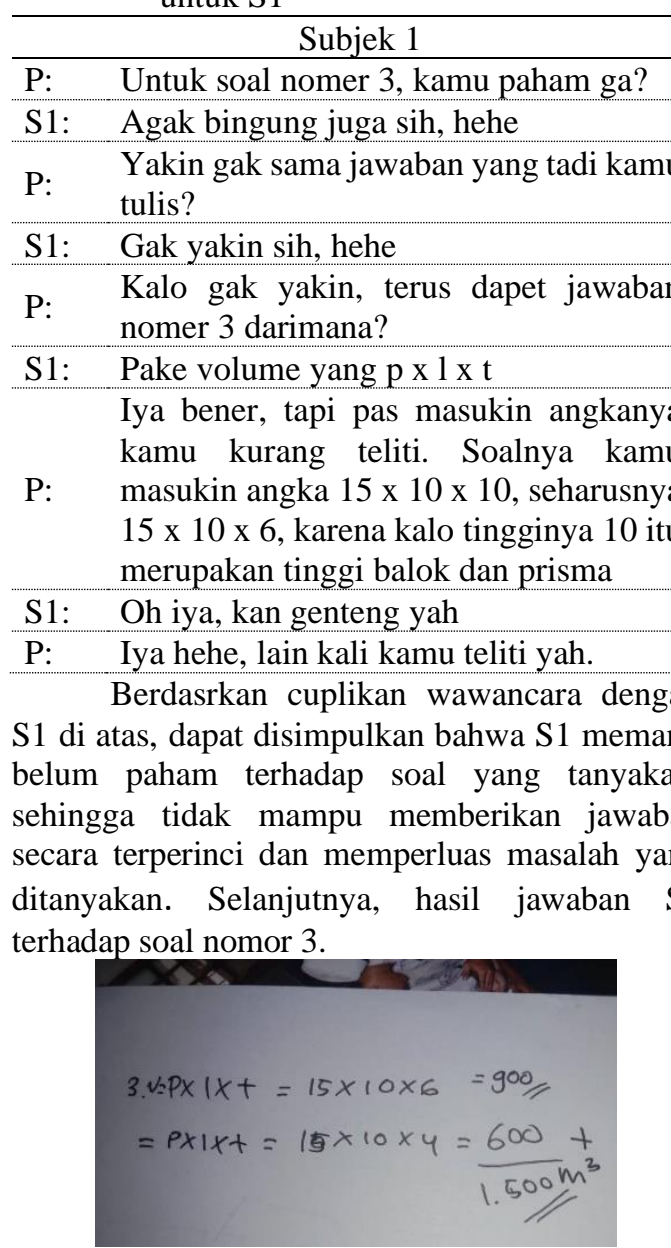

Gambar 11. Jawaban Nomor 3 dari Subjek 2

Berdasrkan jawaban yang diberikan oleh S2 pada gambar 11 di atas, terlihat bahwa S2 juga belum mampu memberikan jawaban dengan teliti, rinci, dan benar. Peneliti melakukan wawancara kepada S2. Berikut cuplikan wawancara soal nomor 3 untuk S2 disajikan pada Tabel 7.

Tabel 7. Cuplikan Wawancara Soal Nomor 3 untuk S2

\begin{tabular}{|c|c|}
\hline \multicolumn{2}{|r|}{ Subjek 2} \\
\hline P: & Soal nomer 3, kamu paham ga? \\
\hline S2: & Aku gak yakin paham, hehe \\
\hline P: & Kalo volume balok sama prisma tau? \\
\hline S2: & Tinggal panjang x lebar x tinggi, kan \\
\hline P: & Kalo itu apa? \\
\hline S2: & Volume... \\
\hline P: & Volume apa? \\
\hline S2: & Balok... \\
\hline P: & Nomer 3 dapet jawaban darimana? \\
\hline S2: & Logika aja... \\
\hline
\end{tabular}

\begin{tabular}{ll} 
P: & Wiih pinter berarti... hehe \\
\hline S2: & Bener gak jawaban saya? \\
& $\begin{array}{l}\text { Yang cara atasnya (volume balok) kamu } \\
\text { benar, untuk yang cara bawahnya } \\
\text { (volume prisma) itu salah ya. Untuk }\end{array}$ \\
P: $\quad \begin{array}{l}\text { jawaban kamu volume balok udah bener } \\
\text { kok sampai situ ajah. Oke lain kali lebih } \\
\text { teliti lagi ya. Makasih banyak yaaa }\end{array}$
\end{tabular}

Berdasrkan cuplikan wawancara dengan S2 di atas, dapat disimpulkan bahwa S2 sudah paham terhadap soal yang diberikan, namun belum bisa memberikan jawaban secara terperinci dan memperluas masalah yang ditanyakan. Selanjutnya, hasil jawaban S3 terhadap soal nomor 3

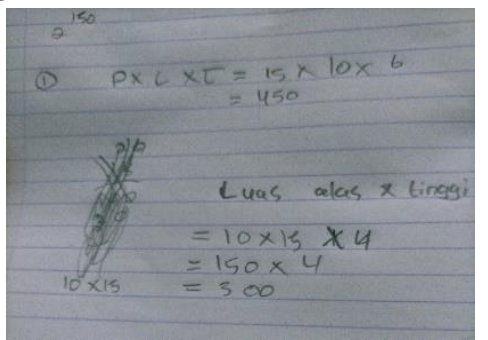

Gambar 12. Jawaban Nomor 3 dari Subjek 3

Berdasrkan jawaban yang diberikan oleh S3 pada gambar 12 di atas, terlihat bahwa S3 juga belum mampu memberikan jawaban dengan teliti, rinci, dan benar. Peneliti melakukan wawancara kepada S3. Berikut cuplikan wawancara soal nomor 3 untuk S3 disajikan pada Tabel 8.

Tabel 8. Cuplikan Wawancara Soal Nomor 3 untuk S3

P: Yang nomer 3, kamu paham ga soalnya?

S3: Yang nomer 3 yang mana soalnya, coba saya liat dulu

P: $\quad$ Yang tentang rumah

S3: Oh iya, kurang paham, itu saya dibantu ayah kalo yang itu

p. Ooh berarti jawabannya dibantu sama ayah kamu?

S3: Iya, saya nanya ayah

P: Volume prisma inget gak?

S3: Lupa.. hehe... itu jawabannya yang volume balok itu kurang. 15 x 10 x 6 bukan 450 . Susunannya sudah benar, tapi perkaliannya yang salah hasilnya,

P: harusnya hasilnya 900. Nah lalu untuk luas prisma nya, hasilnya sudah benar 300 , rumusnya juga kamu benar luas alas $\mathrm{x}$ tinggi, tapi kamu kurang $1 / 2$ nya , lupa ditulis $1 / 2$ nya ya?

S3: Iya... 

$\begin{array}{ll}\text { P: } & \text { Nah tau kan sekarang dimana lupanya... } \\ \text { hehe.. }\end{array}$

Berdasrkan cuplikan wawancara dengan S3 di atas, dapat disimpulkan bahwa S3 belum terlalu paham terhadap soal yang diberikan, namun sudah bisa memberikan jawaban secara terperinci tapi belum mampu memperluas daerah masalah yang diberikan.

Berdasarkan deskripsi 4 subjek penelitian di atas, didapatkan kemampuan berpikir kreatif matematis yang berbeda-beda dipengaruhi oleh gaya kognitif. Hal ini sejalan dengan pernyataan Achir, Usodo, \& Retiawan (2017) bahwa gaya kognitif berpengaruh terhadap pemrosesan informasi dalam otak peserta didik sehingga akan terjadi perbedaan penyampaian ide-ide matematis peserta didik pada masing-masing gaya kognitif. Hasil penelitian Panjaitan (2016) juga menyatakan bahwa proses metakognisi subjek yang bergaya kognitif reflektif berbeda dengan proses metakognisi subjek yang bergaya kognitif impulsif, baik dalam masalah matematika formal maupun matematika kontekstual.

Selain dipengaruhi oleh gaya kognitif, kemampuan berpikir kreatif matematis yang berbeda-beda juga dipengaruhi oleh gender. Sebagaimana pendapat Nur \& Palobo (2018) bahwa gender juga merupakan faktor yang membedakan peserta didik dalam belajar dan mengolah informasi. Subjek yang bergender lakilaki baik bergaya kognitif reflective maupun impulsive lebih mampu berpikir lebih luwes dengan memberikan beberapa cara ketika menyelesaikan masalah matematika atau memberikan beberapa jawaban benar dari pada subjek yang bergender perempuan bergaya kognitif reflective maupun impulsive.

Hal ini sependapat dengan hasil penelitian
Veronica \& Wiryanto (2020) menyaktakan kreativitas peserta didik bergender laki-laki lebih unggul dibanding peserta didik bergender perempuan.

Sedangkan, subjek yang bergender perempuan mampu memberikan jawaban secara terperinci dan memiliki ketelitian lebih baik daripada subjek bergender laki-laki. Hal ini sependapat dengan hasil penelitian Rahayu (2019) yang menyatakan bahwa peserta didik bergender perempuan lebih teliti dan rinci serta dapat memperluas daerah masalah yang diberikan. Rangkuman kemampuan berpikir kreatif matematis subjek penelitian disajikan dalam tabel 9.

\section{SIMPULAN}

Kesimpulan dari hasil penelitian dan pembahasan, subjek yang bergender laki-laki (yaitu S1 dan S3) baik bergaya kognitif reflective maupun impulsive lebih mampu berpikir lebih luwes dengan memberikan beberapa gambar jaring-jaring prisma atau beberapa jawaban benar ketika menyelesaikan masalah matematika dari pada subjek yang bergender perempuan (yaitu S2 dan S4) bergaya kognitif reflective maupun impulsive. Sedangkan, subjek yang bergender perempuan bergaya kognitif impulsive (S4) mampu memberikan jawaban secara terperinci dan memiliki ketelitian lebih baik daripada subjek bergender laki-laki (S1 dan S3).

Implikasi dan temuan penelitian yang telah dilakukan ini, agar kedepannya dapat memperhatikan aspek gaya kognitif dan gender dalam proses pembelajaran matematika dan agar dikembangkan model pembelajaran yang dapat melatih kemampuan berpikir kreatif matematis peserta didik

Tabel 9. Rangkuman Kemampuan Berpikir Kreatif Matematis Subjek Penelitian

\begin{tabular}{ccccc}
\hline \multirow{2}{*}{ No } & Indikator & \multicolumn{3}{c}{ Subjek Penelitian } \\
\cline { 2 - 5 } & S1-Lk Reflective & $\begin{array}{c}\text { Flexibility } \\
\text { (Keluwesan) }\end{array}$ & $\begin{array}{c}\text { Fluency } \\
\text { (Kelancaran) }\end{array}$ & $\begin{array}{c}\text { Elaboration } \\
\text { (Terperinci) }\end{array}$ \\
\hline 1 & S2-Pr Reflective & $\checkmark$ & - & - \\
\hline 2 & S3-Lk Impulsive & - & - & - \\
\hline 3 & S4-Pr Impulsive & $\checkmark$ & - & - \\
4 & & - & - & $\checkmark$
\end{tabular}




\section{DAFTAR PUSTAKA}

Achir, Y. S., Usodo, B., \& Retiawan, R. 2017. Analisis Kemampuan Komunikasi Matematis Siswa Dalam Pemecahan Masalah Matematika Pada Materi Sistem Persamaan Linear Dua Variabel (SPLDV) Ditinjau Dari Gaya Kognitif. Paedagogia, 20(1), 78-87.

Aldarmono, A. 2012. Identifikasi Gaya Kognitif (Cognitive Style) Peserta Didik dalam Belajar. Al-Mabsut: Jurnal Studi Islam Dan Sosial, 3(1), 63-69.

Aprilia, N. C., Sunardi, S., \& Trapsilasiwi, D. 2017. Proses Berpikir Siswa Gaya Kognitif Reflektif dan Impulsif dalam Memecahkan Masalah Matematika di Kelas VII SMPN 11 Jember. Jurnal Edukasi, 2(3), 31-37.

Darmawan, I., Kharismawati, A., Hendriana, H., \& Purwasih, R. 2018. Analisis Kesalahan Siswa SMP Berdasarkan Newman dalam Menyelesaikan Soal Kemampuan Berpikir Kritis Matematis pada Materi Bangun Ruang Sisi Datar. Juring (Journal for Research in Mathematics Learning), 1(1), 71.

Fadiana, M. 2016. Perbedaan Kemampuan Menyelesaikan Soal Cerita Antara Siswa Bergaya Kognitif Reflektif dan Impulsif. Journal of Research and Advances in Mathematics Education, 1(1), 79-89.

Hoang, T. N. 2008. The effects of grade level, gender, and ethnicity on attitude and learning environment in mathematics in high school. International Electronic Journal of Mathematics Education, 3(1), 47-59.

Kagan, J. 1966. Reflection-Impulsivity: The Generality and Dynamics of Conceptual Tempo. Journal of Abnormal Psychology, 71(1), 17.

Kalida, M. 2016. Model Pembelajaran Kreatif Dalam Meningkatkan Minat Membaca Anak Di Luar Sekolah. Hisbah: Jurnal Bimbingan Konseling Dan Dakwah Islam, 12(1), 1-14.

Munandar, M. 2016. Kreativitas \& Keberbakatan Strategi Mewujudkan Potensi Kreatif \& Bakat. Jakarta: PT Gramedia Pustaka Utama.

Nur, A. S., \& Palobo, M. 2018. Profil Kemampuan Pemecahan Masalah Matematika Siswa ditinjau dari Perbedaan Gaya Kognitif dan Gender. Kreano, Jurnal Matematika KreatifInovatif, 9(2), 139-148.

Nurmalia, I., Yuhana, Y., \& Fatah, A. 2019. Analisis Kemampuan Komunikasi Matematis Ditinjau dari Gaya Kognitif pada Siswa SMK. Journal of Authentic Research on Mathematics Education (JARME), 1(2), 105-111.

Nuryadi, \& Rahmawati, P. 2018. Persepsi Siswa Tentang Penerapan Model Pembelajaran Berbasis Proyek Ditinjau dari Kreativitas dan
Hasil Belajar Siswa. Jurnal Mercumatika: Jurnal Penelitian Matematika Dan Pendidikan Matematika, 3(1), 53-62.

OECD. 2019. Programme for International Student Assessment (PISA) 2018 Results. Paris: OECD Publishing.

Panjaitan, B. 2016. Metakognisi Calon Guru Bergaya Kognitif Reflektif dan Kognitif Impulsif dalam Memecahkan Masalah Matematika. Jurnal Cakrawala Pendidikan Universitas Negeri Yogyakarta, XXXV(2), 244-253.

Rahayu, D. S. 2019. Profil Berpikir Kritis Siswa MTs Bergender Perempuan Dalam Menyelesaikan Masalah. Journal Focus Action of Research Mathematic (Factor M), 2(1), 30-38.

Rozencwajg, P., \& Corroyer, D. 2005. Cognitive Processes in The Reflective-Impulsive Cognitive Style. The Journal of Genetic Psychology, 166(4), 451-463.

Siswanto, R. D. 2015. Penerapan Pembelajaran Inkuiri Terbimbing berbantuan GeoGebra untuk Meningkatkan Kemampuan Geometri Spasial, Berpikir Kreatif Matematis dan Kemandirian Belajar Siswa SMP. Bandung: Thesis Universitas Pendidikan Indonesia.

Siswanto, R. D. (2016). Asosiasi Antara Kemampuan Geometri Spasial Dengan Kemampuan Berpikir Kreatif Matematis Siswa. Kalamatika: Jurnal Pendidikan Matematika, 1(2), 141-146.

Siswanto, R. D., \& Awalludin, S. A. 2018. Pengaruh Pembelajaran dengan Menggunakan Mind Map terhadap Kemampuan Berpikir Kreatif Matematis Siswa. Prosiding SENAMKU, 1, 277-288.

Siswanto, R. D., \& Azhar, E. 2018. Workshop Penerapan Software GeoGebra Sebagai Media Pembelajaran Matematika Untuk Guru Sekolah Dasar Kelurahan Pademangan Barat. Publikasi Pendidikan, 8(3), 224-228.

Siswanto, R. D., \& Ratiningsih, R. P. 2020. Korelasi Kemampuan Berpikir Kritis dan Kreatif Matematis dengan Kemampuan Pemecahan Masalah Matematis Materi Bangun Ruang. ANARGYA: Jurnal Ilmiah Pendidikan Matematika, 3(2), 96-103.

Sudia, M., Budayasa, I. K., \& Lukito, A. 2014. Profil Metakognisi Siswa SMP dalam Memecahkan Masalah Terbuka. Jurnal Ilmu Pendidikan, 20(1), 86-93.

Sugiyono. 2018. Metode Penelitian Kuantitatif, Kualitatif, dan R\&D. Bandung: Alfabeta.

Suprihatin, T. R., Maya, R., \& Senjayawati, E. 2018. Analisis Kemampuan Penalaran Matematis Siswa SMP Pada Materi Segitiga dan 
Segiempat. Jurnal Kajian Pembelajaran Matematika, 2(1), 9-13.

Veronica, A. R., \& Wiryanto. 2020. Kreativitas Siswa Sekolah Dasar Berkecerdasan Numerik dalam Memecahkan Soal Eksplorasi Geometri Ditinjau Berdasarkan Gender. Jurnal Penelitian Pendidikan Guru Sekolah Dasar, 8(1), 121-130.

Wardhana, I. R., \& Lutfianto, M. 2018. Analisis Kemampuan Komunikasi Matematis Siswa Ditinjau Dari Kemampuan Matematika Siswa. UNION: Jurnal Ilmiah Pendidikan Matematika, 6(2), 173-184.

Warli, W. 2010. Profil Kreativitas Siswa yang Bergaya Kognitif Reflektif dan Siswa yang Bergaya Kognitif Impulsif dalam Memecahkan Geometri. Universitas Negeri Surabaya. Surabaya: Dissertation Universitas Negeri Surabaya. 